\title{
Gambaran Pasien Stroke Iskemik Akut dengan COVID-19 yang Masuk Ruang Perawatan Intensif
}

\author{
Anastasia T. Thambas, ${ }^{1}$ Diana C. Lalenoh, ${ }^{2}$ Barry I. Kambey ${ }^{2}$
}

\author{
${ }^{1}$ Program Studi Pendidikan Dokter Fakultas Kedokteran Universitas Sam Ratulangi, Manado, \\ Sulawesi Utara, Indonesia \\ ${ }^{2}$ Bagian Anestesiologi dan Terapi Intensif Fakultas Kedokteran Universitas Sam Ratulangi, \\ Manado, Sulawesi Utara, Indonesia \\ Email: tasyathambas@gmail.com
}

\begin{abstract}
Acute ischemic stroke (AIS) has been reported in patients with coronavirus disease 2019 (COVID-19). The cause of AIS in COVID-19 patients has not been fully understood, but COVID-19 is known to cause hypercoagulation characterized by increased d-dimer levels, and cytokine storms. Some AIS patients with COVID-19 require intensive care. This study was aimed to determine the description of AIS patients with COVID-19 admitted to the intensive care unit. This was a literature review study using three databases, as follows: Pubmed, ClinicalKey, and Science Direct. The keywords used were acute ischemic stroke AND COVID-19 AND intensive care unit. The results showed that after being selected based on inclusion and exclusion criteria, 10 literatures were obtained. There were 20 subjects and most were female (55\%) and age group of 60-69 years old (35\%). The most common cardiovascular risk factor was hypertension $(80 \%$, $\mathrm{n}=10$ ). There were some increases in the levels of LDH, CRP, d-dimer, ferritinin, and fibrinogen. On radiological examination performed, there were cases with bilateral pulmonary infiltrate (33\%) and ground-glass opacities $(67 \%)(n=6)$. In conclusion, the characteristics of AIS patients with COVID-19 admitted to the intensive care room were mostly female, age group 60-69 years, had cardiovascular risk factors for hypertension, had elevated levels of LDH, CRP, d-dimer, ferritinin, and fibrinogen, and had ground-glass opacity on radiological imaging.
\end{abstract}

Keywords: acute ischemic stroke, COVID-19, intensive care unit

\begin{abstract}
Abstrak: Stroke iskemik akut telah dilaporkan pada pasien dengan coronavirus disease 2019 (COVID-19). Penyebab stroke iskemik akut pada COVID-19 belum diketahui secara menyeluruh, tetapi COVID-19 dapat menyebabkan kejadian hiperkoagulasi ditandai dengan peningkatan kadar d-dimer serta menyebabkan badai sitokin. Beberapa pasien stroke iskemik akut dengan COVID19 membutuhkan perawatan di ruang perawatan intensif. Penelitian ini bertujuan untuk mengetahui gambaran pasien stroke iskemik akut dengan COVID-19 yang masuk di ruang perawatan intensif. Jenis penelitian ialah literature review dengan pencarian data menggunakan tiga database yaitu Pubmed, ClinicalKey dan Science Direct dengan kata kunci acute ischemic stroke AND COVID-19 AND intensive care unit. Hasil penelitian mendapatkan 10 literatur dengan jumlah subyek penelitian sebanyak 20 orang, jenis kelamin terbanyak ialah perempuan (55\%) dengan kelompok usia terbanyak ialah 60-69 tahun (35\%). Faktor risiko kardiovaskular yang paling banyak dimiliki subyek penelitian ialah hipertensi $(80 \%, n=10)$. Terdapat peningkatan kadar LDH, CRP, d-dimer, ferritinin, dan fibrinogen. Pada pemeriksaan radiologi ditemukan bilateral pulmonary infiltrate (33\%) dan ground-glass opacitiy $(67 \%)(\mathrm{n}=6)$. Simpulan penelitian ini ialah karakteristik pasien stroke iskemik akut dengan COVID-19 yang masuk ruang perawatan intensif paling banyak ialah perempuan, usia 60-69 tahun, memiliki faktor risiko kardiovaskular hipertensi, mengalami peningkatan kadar LDH, CRP, d-dimer, ferritinin, fibrinogen, dan ditemukan ground-glass opacitiy pada gambaran radiologi.
\end{abstract}

Kata kunci: Stroke iskemik akut, COVID-19, ruang perawatan intensif 


\section{PENDAHULUAN}

Sejak pertama kali dilaporkan pada bulan Desember 2019 di Kota Wuhan, Provinsi Hubei, Cina, penyakit coronavirus disease 2019 (COVID-19) terus menyebar ke hampir seluruh dunia dalam waktu singkat. World Health Organization (WHO) telah menetapkan COVID-19 sebagai pandemi dan melaporkan lebih dari 30 juta kasus konfirmasi positif COVID-19 di seluruh dunia. ${ }^{1}$

Data terakhir dari WHO pada tanggal 5 Oktober tahun 2020 dilaporkan sebanyak 35,1 juta kasus positif COVID-19 di seluruh dunia dengan angka kematian mencapai 1 juta kasus. Di Asia Tenggara, Filipina menempati urutan pertama negara dengan kasus konfirmasi COVID-19 terbanyak yaitu 314 ribu kasus dan 5 ribu kasus kematian. Indonesia menempati urutan ke dua dengan jumlah kasus COVID-19 sebanyak 307 ribu kasus dengan jumlah kematian 11,2 ribu kasus. Sulawesi Utara menyumbang 4,329 kasus positif COVID19 dan 171 kasus di antaranya ialah kasus kematian. $^{1,2}$

Virus penyebab infeksi COVID-19 yang menyebar sangat pesat dalam waktu singkat ini ialah severe acute respiratory syndrome coronavirus 2 (SARS-CoV-2). Masa inkubasi virus SARS-CoV-2 ialah 114 hari dengan rerata 5-6 hari setelah terinfeksi. Tanda dan gejala umum dari COVID-19 yaitu demam $\left(\geq 38^{\circ} \mathrm{C}\right)$, batuk kering, sesak napas, dan kelelahan. ${ }^{3}$

Selain dari tanda dan gejala umum COVID-19, pada kasus COVID-19 yang lebih berat dilaporkan memiliki manifestasi neurologik. Kasus berat COVID-19 dengan faktor risiko kardiovaskular memiliki kecenderungan untuk penyakit serebrovaskular. ${ }^{4}$ Beberapa penelitian terbaru menunjukkan peningkatan kadar D-dimer pada infeksi SARS-CoV-2 yang berat; hal ini diduga menjadi penyebab terjadinya penyakit serebrovaskular seperti stroke iskemik akut pada pasien COVID-19., SARS-CoV-2 juga dapat menyebabkan badai sitokin karena peningkatan reseptor angiotensin-converting enzyme 2 (ACE 2) sehingga terjadi hiperkoagulasi dan pening- katan kejadian trombosis vaskuler pada pasien dengan COVID-19. ${ }^{6}$ Sekitar $6 \%$ pasien yang masuk rumah sakit dengan diagnosis COVID-19 menderita stroke; $80 \%$ di antaranya ialah stroke iskemik akut. ${ }^{4}$

Pada penelitian retrospektif observasional terhadap 214 pasien konfirmasi positif COVID-19 di Wuhan, sebanyak 5,7\% pasien kasus berat COVID-19 menderita stroke iskemik akut $(\mathrm{n}=88) .{ }^{4}$ Penelitian retrospektif case-control di New York menunjukkan kasus stroke iskemik akut dengan hasil tes reverse transcription polymerase chain reaction (RT-PCR) positif COVID-19 sebanyak 46,3\% (n=41). ${ }^{7}$ Dua dari empat pasien stroke iskemik akut dengan COVID-19 membutuhkan perawatan di ruang perawatan intensif IV (ICU). ${ }^{8}$ Penelitian retrospektif kohort di Milan mencatat sebanyak $33,3 \%$ pasien stroke iskemik dengan COVID-19 masuk di ruang ICU. ${ }^{9}$

Mengingat pentingnya profil pasien stroke iskemik akut dengan COVID-19 yang membutuhkan perawatan di ICU penting untuk penatalaksanaan pasien maka penulis terdorong untuk melakukan kajian ilmiah mengenai gambaran pasien stroke iskemik akut dengan COVID-19 yang masuk di ruang perawatan intensif.

\section{METODE PENELITIAN}

Penelitian ini berbentuk literature review dengan melakukan pencarian data mengggunakan tiga database dengan kriteria yang ditentukan yaitu Pubmed, ClinicalKey dan Science Direct. Kata kunci yang digunakan dalam pencarian literatur yaitu acute ischemic stroke AND COVID-19 AND intensive care unit.

\section{HASIL PENELITIAN}

Setelah melalui tahap seleksi literature, didapatkan 10 literatur yang memenuhi kriteria inklusi dengan total jumlah subyek penelitian dari 10 literatur tersebut ialah sebanyak 20 pasien.

Tabel 1 memperlihatkan karakteristik menurut demografi dari pasien stroke iskemik akut dengan COVID-19 yang masuk ruang ICU. Jenis kelamin yang terbanyak ialah perempuan, yaitu sebanyak 
11 orang $(55 \%)$. Kelompok usia subyek penelitian terbanyak ialah 60-69 tahun, yaitu sebanyak tujuh orang $(35 \%)$. ${ }^{8,9,11-18}$

Tabel 1. Karakteristik subyek penelitian menurut demografi. $8,9,11-18$

\begin{tabular}{lll}
\hline \multicolumn{1}{c}{ Data subyek } & N & \% \\
\hline Jenis kelamin & & \\
Laki-laki & 9 & 45 \\
Perempuan & 11 & 55 \\
Usia & & \\
30-39 tahun & 1 & 5 \\
40-49 tahun & 3 & 15 \\
50-59 tahun & 5 & 25 \\
60-69 tahun & 7 & 35 \\
70-79 tahun & 2 & 10 \\
$\geq 80$ tahun & 2 & 10 \\
\hline
\end{tabular}

Tabel 2 memperlihatkan data keseluruhan dari karakteristik subyek penelitian menurut faktor risiko kardiovaskular yang terbagi atas hipertensi $(80 \%)$, diabetes melitus $(50 \%)$, obesitas $(10 \%)$, dislipidemia $(10 \%)$, atrial fibrilasi (10\%), penyakit kardiovaskular (30\%), dan perokok $(20 \%)$. $^{11-13,15-19}$

Tabel 2. Karakteristik subyek penelitian menurut faktor risiko. ${ }^{8,11,12,14-18}$

\begin{tabular}{lll}
\hline \multicolumn{1}{c}{ Faktor risiko } & N=10 & \% \\
\hline Hipertesi & 8 & 80 \\
Diabetes melitus & 5 & 50 \\
Obesitas & 1 & 10 \\
Dislipidemia & 1 & 10 \\
Atrial fibrilasi & 1 & 10 \\
Penyakit & 3 & 30 \\
Kardiovaskular & & \\
Perokok & 2 & 20 \\
\hline
\end{tabular}

Tabel 3 memperlihatkan dari 10 literatur yang diteliti, masing-masing menyajikan hasil pemeriksaan laboratorium yang dilakukan pada subyek penelitian. Hasil pemeriksaan laboratorium terbagi atas pemeriksaan hemoglobin, leukosit, neutronfil, limfosit, laktat dehidrogenase (LDH), $C$ reactive protein (CRP), fibrinogen, $\mathrm{d}$-dimer, dan ferritinin.
Pada semua subyek penelitian yang dilakukan pemeriksaan kadar LDH dan CRP terlihat peningkatan pada kadar LDH dan CRP. Hasil pemeriksaan kadar d-dimer menunjukkan peningkatan pada $82 \%$ subyek penelitian $(\mathrm{n}=17)$. Kadar ferritinin juga meningkat pada $77 \%$ subyek penelitian $(\mathrm{n}=13){ }^{9-18}$

Tabel 4 memperlihatkan gambaran pemeriksaan radiologi dada menggunakan X-ray dan computed tomography scan (CT Scan). Pada dua subyek penelitian dilakukan pemeriksaan X-ray yang menunjukkan adanya bilateral pulmonary infiltrat (33\%). Sebanyak 4 subyek penelitian menunjukkan ground-glass opacitiy (GGO) pada hasil pemeriksaan CT scan dada (67\%). ${ }^{13,14,17,18}$

Tabel 3. Karakteristik subyek penelitian menurut gambaran laboratorium. ${ }^{8,9,11-18}$

\begin{tabular}{|c|c|c|}
\hline $\begin{array}{c}\text { Hasil } \\
\text { pemeriksaan } \\
\text { laboratorium } \\
\end{array}$ & $\mathbf{N}$ & $\%$ \\
\hline \multicolumn{3}{|l|}{ Hemoglobin } \\
\hline Normal & 2 & 40 \\
\hline Anemia & 3 & 60 \\
\hline \multicolumn{3}{|l|}{ Leukosit } \\
\hline Normal & 6 & 75 \\
\hline Leukositosis & 2 & 25 \\
\hline \multicolumn{3}{|l|}{ Neutrofil } \\
\hline Normal & 4 & 57 \\
\hline Neutrofilia & 3 & 43 \\
\hline \multicolumn{3}{|l|}{ Limfosit } \\
\hline Normal & 10 & 71 \\
\hline Limfopenia & 4 & 29 \\
\hline \multicolumn{3}{|l|}{$\mathrm{LDH}$} \\
\hline Meningkat & 7 & 100 \\
\hline \multicolumn{3}{|l|}{$\mathrm{CRP}$} \\
\hline Meningkat & 7 & 100 \\
\hline \multicolumn{3}{|l|}{ Fibrinogen } \\
\hline Normal & 1 & 17 \\
\hline Meningkat & 5 & 83 \\
\hline \multicolumn{3}{|l|}{ D-dimer } \\
\hline Normal & 3 & 18 \\
\hline Meningkat & 14 & 82 \\
\hline \multicolumn{3}{|l|}{ Ferritinin } \\
\hline Normal & 3 & 23 \\
\hline Meningkat & 10 & 77 \\
\hline
\end{tabular}


Tabel 4. Karakteristik subyek penelitian menurut gambaran radiologik (dada). ${ }^{12,13,16,17}$

\begin{tabular}{lll}
\hline Gambaran radiologik & $\mathbf{N = 6}$ & $\mathbf{\%}$ \\
\hline X-Ray & & \\
$\quad \begin{array}{l}\text { Bilateral pulmonary } \\
\text { infiltrate }\end{array}$ & 2 & 33 \\
CT Scan & & \\
$\quad$ GGO & & \\
Konsolidasi & 2 & 67 \\
$\quad$ Efusi pleura & 1 & 17 \\
\hline
\end{tabular}

\section{BAHASAN}

Hasil penelitian ini menunjukkan jenis kelamin perempuan lebih banyak membutuhkan perawatan di ruang ICU pada pasien stroke iskemik akut dengan COVID$19(55 \%)$ dibandingkan jenis kelamin lakilaki $(45 \%)$. Untuk kelompok usia, posisi pertama yang paling banyak membutuhkan perawatan di ruang ICU ialah kelompok usia 60-69 tahun (35\%), diikuti oleh kelompok usia 50-59 tahun (25\%), kelompok usia 4049 tahun (15\%), kelompok usia 70-79 tahun $(10 \%)$ dan $\geq 80$ tahun $(10 \%)$, serta kelompok usia 30-39 tahun (5\%) (Tabel 1).

Usia >55 tahun merupakan salah satu faktor risiko terjadinya stroke iskemik akut dan kelompok usia >65 tahun rentan terpapar virus SARS-CoV-2 serta memiliki angka mortalitas yang cukup tinggi. Kelompok usia ini juga memiliki tingkat severity dari COVID-19 berat yang menyebabkan banyak pasien pada kelompok usia ini membutuhkan bantuan ventilator mekanik dan masuk ke ruang ICU. ${ }^{19,20}$

Terdapat berbagai faktor risiko pada subyek penelitian sampai terjadinya onset stroke iskemik akut pada pasien COVID-19. Data subyek penelitian dengan faktor risiko jika menggunakan klasifikasi International Classification of Disease (ICD) 10 menunjukkan bahwa penyakit sirkulasi ialah faktor risiko yang paling mendominasi dengan hipertensi (80\%), atrial fibrilasi (10\%), dan penyakit kardiovaskular lainnya (30\%) (Tabel 2). Roncon et $\mathrm{al}^{21}$ menyatakan bahwa hipertensi meningkatkan risiko masuk ICU pada pasien COVID-19 ( $\mathrm{p}<0,0001)$.

Penyakit endokrin, nutrisi, dan metabolik juga merupakan faktor risiko yang banyak ditemukan pada subyek penelitian yaitu diabetes melitus (50\%), obesitas (10\%), dan dislipidemia (10\%) (Tabel 2). Diabetes melitus ialah salah satu komorbid paling serius terkait keparahan dari SARSCoV-2. Diabetes dikaitkan dengan early outcome yang buruk pada pasien COVID-19 yang masuk rumah sakit. $^{22}$ Menurut penelitian oleh Seiglie et al, $^{23}$ dari 450 pasien COVID-19 sebanyak 178 pasien menderita diabetes dan persentase pasien COVID-19 yang masuk ICU lebih tinggi pada pasien dengan diabetes dibandingkan pasien yang tidak menyandang diabetes, yaitu $42.1 \%$ banding $29.8 \%(\mathrm{p}=0,007)$.

Hasil-hasil pemeriksaan laboratorium abnormal yang mendominasi di antaranya ialah anemia (60\%), peningkatan kadar LDH (100\%), peningkatan kadar CRP (100\%), peningkatan kadar fibrinogen (83\%), peningkatan kadar d-dimer (82\%), dan peningkatan kadar ferritinin (77\%) (Tabel 3).

Studi terbaru dari Mehta et $\mathrm{al}^{6}$ dan Tay et $\mathrm{al}^{24}$ menyatakan adanya hubungan infeksi pada pasien SARS-CoV-2 dengan hiperinflamasi termasuk kejadian badai sitokin dan keadaan hiperkoagulabilitas. Dari hasil analisis oleh Valencia-Enciso et al, ${ }^{25}$ aktivasi berlebihan dari kedua keadaan tersebut terbukti dengan meningkatnya kadar ddimer, fibrinogen, CRP, ferritinin, dan LDH. Namun demikian, data dari literatur yang dikaji belum dapat disimpulkan secara bermakna oleh karena kurangnya sampel penelitian serta tidak dilakukan uji statistik.

Temuan gambaran radiologik dada pada pasien stroke iskemik akut dengan COVID-19 yang masuk ruang ICU bervariasi. Pada hasil X-ray terlihat bercak di pinggir paru yang kemudian berkembang menjadi bilateral pulmonary infiltrate (33\%). Pada CT scan terlihat GGO (67\%), konsolidasi paru (33\%), dan ada juga efusi pleura $(17 \%) .{ }^{12,13,16,17}$

\section{SIMPULAN}

Karakteristik pasien stroke iskemik akut dengan COVID-19 yang masuk ruang perawatan intensif paling banyak ialah jenis kelamin perempuan, kelompok usia 60-69 tahun, memiliki faktor risiko kardiovaskular 
hipertensi, mengalami peningkatan kadar LDH, CRP, d-dimer, ferritinin, fibrinogen, dan ditemukan GGO pada gambaran radiologik.

Penelitian lanjut dan mendalam yang spesifik tentang pasien stroke iskemik akut dengan COVID-19 yang membutuhkan perawatan di ruang ICU dapat dilakukan untuk mengetahui karakteristik yang lebih lengkap dari pasien dengan kondisi tersebut.

\section{Konflik Kepentingan}

Penulis menyatakan tidak terdapat konflik kepentingan dalam studi ini.

\section{DAFTAR PUSTAKA}

1. WHO Coronavirus Disease (COVID-19) Dashboard [Internet]. Available from: https://covid19.who.int/

2. Situasi Terkini Perkembangan Corona-virus Disease (COVID-19) 22 September 2020 Info Infeksi Emerging Kementerian Kesehatan RI [Internet]. Available from: https://covid19.kemkes.go.id/ situasi-infeksi-emerging/ info-coronavirus/situasi-terkini-perkembangancoronavirus-disease-covid-19-23september-2020/ \#.X3vEx2gzZPY

3. WHO China Joint Mission on COVID-19 Final Report [Internet]. Available from: https://www.who.int/docs/defaultsource/ coronaviruse/who-china-jointmission-on-covid-19-final-report.pdf

4. Mao L, Jin H, Wang M, Hu Y, Chen S, He Q, et al. Neurologic manifestations of hospitalized patients with coronavirus disease 2019 in Wuhan, China. JAMA Neurol. 2020;77(6):683-690.

5. Wu Y, Xu X, Chen Z, Duan J, Hashimoto K, Yang L, et al. Nervous system involvement after infection with COVID-19 and other coronaviruses. Brain Behav Immun. 2020;87:18-22.

6. Mehta P, McAuley DF, Brown M, Sanchez E, Tattersall RS, Manson JJ. COVID19: consider cytokine storm syndromes and immunosuppression. Lancet. 2020; 395(10229):1033-4.

7. Belani P, Schefflein J, Kihira S, Rigney B, Delman BN, Mahmoudi K, et al. COVID-19 is an independent risk factor for acute ischemic stroke. American Journal of Neuroradiology. 2020;41. DOI: https://doi.org/10.3174/ajnr.
A6650

8. Barrios-López JM, Rego-García I, Muñoz Martínez C, Romero- Fábrega JC, Rivero Rodríguez M, Ruiz Giménez JA, et al. Ischaemic stroke and SARS-CoV2 infection: a causal or incidental association? Neurología (English ed). 2020;35(5):295-302.

9. Lodigiani C, Iapichino G, Carenzo L, Cecconi M, Ferrazzi P, Sebastian T, et al. Venous and arterial thromboembolic complications in COVID-19 patients admitted to an academic hospital in Milan, Italy. Thromb Res. 2020;191:9-14.

10. Dafer RM, Osteraas ND, Biller J. Acute stroke care in the coronavirus disease 2019 pandemic. J Stroke Cerebrovasc Dis. 2020;29(7):104881.

11. Beyrouti R, Adams ME, Benjamin L, Cohen H, Farmer SF, Goh YY, et al. Characteristics of ischaemic stroke associated with COVID-19. J Neurol Neurosurg Psychiatry. 2020;91(8):889-91.

12. Sharifi-Razavi A, Karimi N, Zarvani A, Cheraghmakani $\mathrm{H}$, Baghbanian SM. Ischemic stroke associated with novel coronavirus 2019: a report of three cases. Int J Neurosci. 2020:1-5. Doi:10.1080/00207454.2020.1782902

13. Paterson RW, Brown RL, Benjamin L, Nortley R, Wiethoff S, Bharucha T, et al. The emerging spectrum of COVID19 neurology: clinical, radiological and laboratory findings. Brain. 2020;143 (10):3104-20.

14. Requena M, Olivé-Gadea M, Muchada M, García-Tornel Á, Deck M, Juega J, et al. COVID-19 and stroke: incidence and etiological description in a high-volume center. J Stroke Cerebrovasc Dis. 2020; 29(11):1-8.

15. Co COC, Yu JRT, Laxamana LC, David-Ona DIA. Intravenous thrombolysis for stroke in a COVID-19 positive filipino patient, a case report. J Clin Neurosci. 2020;77:234-6.

16. Morassi M, Bagatto D, Cobelli M, Serena D'agostini, Gigli GL, Bnà C, et al. Stroke in patients with SARS-CoV-2 infection: case series. J Neurol. 2020; 267(8):2185-2192.

17. Kisabay AK, Çetin G, Batum M. The acute ischemic stroke induced by Covid-19 disease - a case report. Integr J Med Sci. $2020 ; 7$. 
18. Mahboob S, Boppana SH, Rose NB, Beutler BD, Tabaac BJ. Large vessel stroke and COVID-19: Case report and literature review. eNeurologicalSci. 2020;20: 100250.

19. Seshadri S, Beiser A, Kelly-Hayes M, Kase CS, Au R, Kannel WB, et al. The lifetime risk of stroke: estimates from the Framingham study. Stroke. 2006;37(2): 345-50.

20. Bialek S, Boundy E, Bowen V, Chow N, Cohn A, Dowling N, et al. Severe outcomes among patients with coronavirus disease 2019 (COVID-19) - United States, February 12-March 16, 2020. Morb Mortal Wkly Rep (MMWR) 2020; 69(12):343-6.

21. Roncon L, Zuin M, Zuliani G, Rigatelli G. Patients with arterial hypertension and COVID-19 are at higher risk of ICU admission. Br J Anaesth. 2020;125(2): e254-5.

22. Certain medical conditions and risk for severe
COVID-19 Illness. CDC [Internet]. Available from: https://www.cdc.gov/ coronavirus/2019-ncov/need-extraprecautions/people-with-medicalconditions.html

23. Seiglie J, Platt J, Cromer SJ, Bunda B, Foulkes AS, Bassett I V, et al. Diabetes as a risk factor for poor early outcomes in patients hospitalized with covid-19. Diab Care. 2020;43(12):2938-44.

24. Zirui Tay M, Meng Poh C, Ramp L, MacAry PA, P Ng LF. The trinity of COVID-19: immunity, inflammation and intervention. Nat Rev Immunol. 2020;20(6): 363-74.

25. Valencia-Enciso N, Ortiz-Pereira M, ZafraSierra MP, Espinel-Gómez L, Bayona $\mathrm{H}$. Time of stroke onset in coronavirus disease 2019 patients around the globe: a systematic review and analysis. J Stroke Cerebrovasc Dis. 2020;29(12): 105325. 